\title{
Feminine and Failed Suicides in Spanish Cinema
}

Este artículo analiza cómo el suicidio frustrado de las protagonistas de ¿Qué he hecho yo para merecer esto!! (Pedro Almodóvar, 1984) y Costa Brava (Family Album) (Marta Balletbò-Coll, 1995) es esencial para entender el lugar de estas dos mujeres en relación con los modelos de género de la España de los 80 y 9o. Argüimos que el acto de suicidio es más que una elección individual, puesto que surge de una serie de coyunturas sociológicas y de género. A su vez, consideramos que el suicidio fallido puede ayudarnos a entender cómo se presenta la autoría y la reescritura del mito de Edipo en las dos películas.

Palabras claves: ¿Qué he hecho yo para merecer esto!!, Pedro Almodóvar, Costa Brava (Family Album), Marta Balletbò-Coll, suicidio, género, autoría, cine

This article analyzes how the failed suicides of the female protagonists of the films ¿Qué he hecho yo para merecer esto!! (Pedro Almodóvar, 1984) and Costa Brava (Family Album) (1995) are key to understanding the position of these characters with regard to Spain's gender models during the 8os and 9os. We argue that suicide is more than an individual decision, because it arises from sociological factors and gender presumptions and expectations. In addition, we consider failed suicide as essential in understanding the question of authorship and the revision of the Oedipal myth in these two films.

Keywords: ¿Qué he hecho yo para merecer esto!!, Pedro Almodóvar, Costa Brava (Family Album), Marta Balletbò-Coll, suicide, gender, authorship, film

This article explores how the female protagonists of two Spanish films Gloria (interpreted by Carmen Maura) from ¿Qué he hecho yo para merecer esto!! (Pedro Almodóvar, 1984) and Anna (interpreted by the movie's director Marta Balletbò-Coll) from Costa Brava (Family Album) (1995) contemplate suicide in a similar way; they both imagine jumping from the balcony or window of their houses, but neither attempts the act. We argue that failed suicide in both films is central in understanding the position of the female protagonists vis-à-vis the changing gender norms and 
expectations dominant in 1980 o and 1990 S Spain, as well as in illuminating the protagonists' relationship with their work (both paid and unpaid, inside and outside the home), their bodies and their sense of agency. More importantly, suicide functions in these two movies to revise the Oedipal narrative; in both works, the relationship between actress and director is reimagined within the suicidal act, and thus the scenes of the protagonists' failed suicide question the power relations of the directors and the actresses. While these two films have been examined from a gender studies perspective, no study has compared nor discussed them within a framework of research on suicide theory and in relation to the centrality of suicide in the Oedipal process. ${ }^{\mathrm{I}}$

Gloria and Anna represent two distinct models of womanhood. Gloria is a working-class mother who initially lives in a tiny apartment in the outskirts of Madrid with her sexist husband, their two sons and her mother-in-law, and who feels overwhelmed by her many responsibilities. Anna is a liberated young professional; she is conscious about women's oppression, but still has to negotiate her work and personal life as she embarks on a romantic relationship with Montserrat Ehrzman-Rosas (interpreted by Desi del Valle), a Jewish-American female engineer who lives in Barcelona. The severity with which the two characters portray suicide also varies significantly in these two movies. In ¿Qué he hecho yo para merecer esto!!, Gloria considers suicide when she feels that her life is void of purpose. After her husband's death, and with her two sons and mother-in-law no longer at home, she is left alone in their apartment. The protagonist of Costa Brava, Anna, casually teases Montserrat, her partner, that she will take her life, although she shows no real intention of doing so. But even though Gloria's situation is certainly more dire, comedic relief is present in both films; Almodóvar's film incorporates a twisted and hyperdramatic humour, while comedy in Costa Brava is evoked with stereotypical exaggeration. ${ }^{2}$

These two films are eleven years apart in their production and portray two distinct geographical and historical moments in Spain: ¿Qué he hecho yo para merecer esto!! takes place in Madrid during the 8 os - years well known for the countercultural movement of the Movida madrileña; ${ }^{3}$ Costa Brava is set in Barcelona and the Catalan coast in 1995 - soon after the Olympic games. Yet both films show how sexual identities and gender expectations reflect traditional attitudes during the 8os and 9os in Spain. Both were produced at a moment in which ideas surrounding normative sexuality, as well as gender roles and expectations were dramatically shifting. Although Almodóvar has expressed his "wish to make films as though Franco never existed" (see Strauss 29), critics have signalled the 
weight that Spain's Francoist history has on his films. Something similar happens with Costa Brava, a movie about a lesbian couple, but in which the figure of a housewife who incarnates a model of traditional thinking serves as the protagonist's alter ego.

These films allow us to consider the centrality of suicide in relation to gender issues during the 8 os and 9os in Spain. In addition, the two protagonists' attitude towards suicide also points to the intricacies of queer cinema in Spain and issues of authorship. Almodóvar's ¿Qué he hecho yo para merecer esto!! is one of the best known films of a director who has been globally acclaimed and who could be considered an international representative of Spanish culture. Contrary to that, and despite being hailed as the first Spanish feature film that explicitly focuses on lesbian identity (Yeon-Soo 469), Costa Brava is not a well-known movie, and has received little official recognition. However, the film did win the award for best film at the San Francisco International Lesbian \& Gay Film Festival in 1995 and at the Catalan film awards (Sant Jordi awards) in 1996, and was nominated by the GLAAD Media Awards in 1997 ("Costa Brava, Awards"). ${ }^{4}$

Central to our reading of these two movies is the work by the social philosopher Katrina Jaworski, and more specifically, her article "The Gender-ing of Sucide" (2010) and her book The Gender of Suicide (2014). In these two works, Jaworski argues that societal norms create a false sense of personal agency, and that gender is a social process at the core of suicide (see "The Gender-ing" 47). Jaworski's studies consider how the discourse surrounding suicide is outdated, a "masculinist construction" largely influenced by the work of Emile Durkheim's Suicide: A Study in Sociology (originally Le suicide and published in $\mathrm{I} 897$ ). Contrary to that, for Jaworski, suicide is a manifestation of social processes that extend far past individual autonomy. In addition, Jaworski highlights how committing suicide is a masculine act, which is reinforced by gender norms and illustrated in statistics that reveal that men and women attempt suicide at nearly equal rates but that men are much more "successful" at carrying out the act (see "The Gender-ing" 56). In other words, according to Jaworski, to survive is to fail, and to fail is a sign of femininity (see The Gender-ing" 56-56).

While Jaworski's statistics stem from an Australian context and her work has been influenced by English-speaking scholarship and research, her ideas also resonate in the Spanish context, where gender and sex are also situated in a masculine/feminine binary, which implies a normative set of expectations and roles. Franco's regime reinforced the values of the Catholic Church in Spanish society and reaffirmed traditional gender roles. During Francoism, women were expected to demonstrate a submissive 
femininity with adherence to Church values and duties as "good" wives and mothers at the forefront of societal morality. Such roles cemented their proper position as housewives, and by default, the centrality of the home in Spanish society's definition of femininity.5 "Spain did not experience first- or second-wave feminism simultaneously with its European neighbors due primarily, albeit not exclusively, to the Franco dictatorship (1939-1975)" (I057), affirms Duncan Wheeler. However, while Spain did not necessarily follow the same evolution of feminism as its European counterparts, its post-dictatorship trajectory, which maintained strict gender norms, aligns well with the goals of second-wave feminism that began in the early 6os. This movement identified gender roles at a time when many began to confront inequalities particularly with respect to women's experience at home and work, as well as with regards to issues of normative gender identity and sexuality.

Even more important is how the gender discrepancy signalled by Jaworski is also reflected in Spanish statistics. Table I demonstrates the prominence of gender disparities in suicide in Spain and depicts how a system of norms shaped the understanding and practice of suicide between 1986 and 2002. As Jaworski reminds us, such norms seep into many facets of society: the legal, medical, psychiatric, social and statistical institutions and media bodies all influence how suicide is conceptualized and practiced in everyday contexts (see The Gender of Suicide 77). Between I986 and 2002, men in Spain were three times more likely to commit suicide than women. ${ }^{6}$ These statistics seem to confirm the dichotomy noted by Jaworski in which fewer women die of suicide than men, even though both attempt suicide at similar rates. This is also reflected in the films studied here, where the female protagonists foresee the act of suicide, but neither of them carries it out.

Released in 1984, Almodóvar's ¿Qué he hecho yo para merecer esto!! represents the difficult position of women vis-à-vis their experience at home and work. Gloria receives little gratitude from her family for her professional work as a cleaner. Instead, she receives disgruntled complaints from her husband and mother-in-law when she fails to adequately tend to their needs. For example, at the beginning of the movie, her husband Antonio comes home from work and complains about the meal Gloria has prepared for him, stating: "Estoy trabajando todo el día como un cabrón. Llego a casa y tengo que comer un pollo medio quemado y ni siquiera puedo tomar un vaso de vino, ijoder!" (I2:37). Although she also worked all day outside the home, her husband does not recognize her efforts and expects her to serve him after his day has finished. Gloria is supposed to remain unbothered by such thankless demands and 
responsibilities. Her mother-in-law remarks, "Te va a dar algo" (20:00), which not only foreshadows Gloria's "crisis," but also implies that Gloria is overreacting. While her family does not acknowledge the difficulties of her position, others, like her neighbour Cristal - who engages in prostitution do. Cristal justifies Gloria's "hysterical" (22:26) behaviour as resulting from the fact that Gloria "[está] todo el día trabajando de asistente y con dos hijos" (22:30). Furious at her family, the protagonist affirms the importance of her presence in the house when she exclaims: "Estoy de vosotros hasta la coronilla. El día menos pensado me largo, y a ver cómo os apañáis sin mí" (40:35). With this sentence and with the various interactions with her family and daily work schedule, she portrays a somehow stereotypical Spanish mother who requests that her family minimally recognize the innumerable sacrifices she makes for them and the significance of her work - both outside and inside the home - despite the fact that she feels invisible and socially under-appreciated. ${ }^{7}$

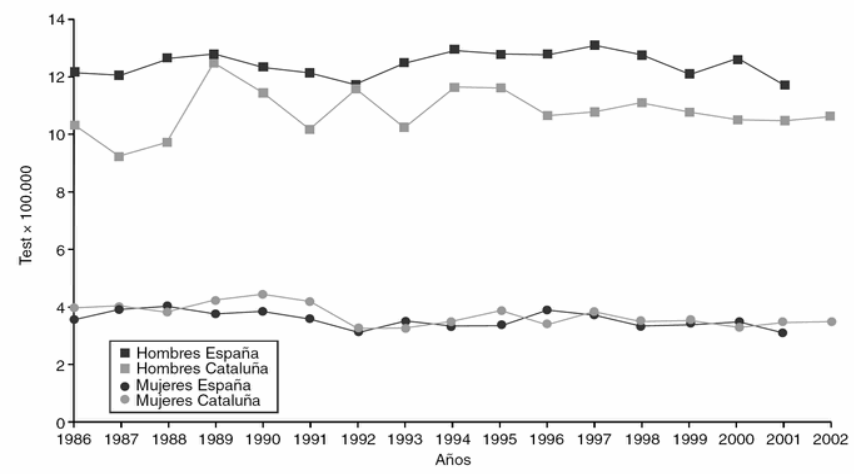

Table I

Suicide mortality rates in Spain and Catalonia from 1986 to 2002 according to gender (Arán Barés, María, Gispert Rosa, et al. 476)

Even though Gloria threatens to leave her family, she feels trapped in her domestic position. She nonetheless presents an interesting paradox about her perception of her social role, because, in spite of feeling trapped, she suggests that the role she occupies in society could be avoided. Gloria's attitude towards education (focused on the possibility of social mobility) becomes evident at one point in the film when she advises a young girl to stay in school suggesting: "sí no vas al colegio, ya sabes lo que te espera: 
servir como yo; servir o hacer la carrera como la Cristal" (30:26). In such a way, Gloria realizes that society functions systemically, and some, like herself and Cristal, are disadvantaged, either by their own choices or by the inner workings of society. Throughout the film, Gloria indirectly grapples with how society's tiers of power frame her life and her agency within it. Her motivation seems to progress over time from what is initially a lack of desire and enthusiasm to fulfill her responsibilities, to what some, like her mother-in-law, might call a crisis. Gloria takes, however, certain inadvertent steps to liberate herself from her duties. This becomes noticeable when Gloria offers her son Miguel to a perverted dentist when she is unable to pay the dentist's bills. This scene reveals Gloria's terrible mothering, and in a shocking and dark way, is humorous. But the audience still recognizes Gloria's deliberate decision as one that was influenced by circumstances partially outside of her control.

Gloria's resistance to her housewife responsibilities relates to the notion of "feminine mystique," coined by Betty Friedan's 1963 book of the same title. In her groundbreaking study, Friedan identifies as false the idea that women in the I950s in the United States felt fulfilled in their roles as housewives. ${ }^{8}$ Friedan's work helped spark the second wave feminist movement in which women questioned and challenged their roles at home and the workplace (Frechette 129). In this regard Gloria's desires and actions resemble the frame of mind of second wave feminism because she seeks better treatment and recognition for her gendered position as a mother and wife. Yet even though she seeks liberation, she also feels that she cannot live without domestic responsibilities. In this way, Gloria experiences a paradoxical situation: she cannot be happy with her responsibilities, but without them, her life is void of meaning. While sociologists like Emile Durkheim suggest that gender normativity might benefit women in the sense that their socialization into domestic roles "protects" them from "successful suicide," and even if it is true that they commit suicide at lower rates, the private sphere quite often tends to be the most dangerous place for women, something that is clearly evident in the case of Gloria, whose cleaning and care-giving responsibilities are the major sources of her unhappiness.

However, the confinement in traditional roles might not be fully responsible for Gloria's feeling of imprisonment and dissatisfaction. The notion known as the "feminist mystique" - not to be mistaken for the previously introduced, "feminine mystique" - recognizes how feminist movements, particularly those that fight for women's equality in the workplace, might also create an "either/or binary for women in public and private spheres, making it difficult for women to choose freely between a 
feminist view of sexual and professional liberation and traditional values associated with femininity, motherhood, and housewifery" (Frechette I29). In other words, women's liberation through payed work might not necessarily constitute a complete liberation, especially if we take into consideration the kind of work these women do. The binaries of both mystiques are somehow represented in Gloria's actions and suicidal thoughts: she is not only trapped by her duties inside the home and as a mother, but she also has a job outside the home, one which nonetheless does not provide her with complete freedom. In some ways, remunerated work places her further from reaching any kind of equality with her husband, as it only means that she must work twice as hard in order to complete her duties both inside and outside the home. Despite the seriousness of her attempts to free herself from her suffering, she remains victim to outside forces that confine her to making decisions within a system of expected behaviour and norms.

A major scene regarding her freedom is when Gloria and Antonio are arguing about her domestic underperformance. Infuriated, Antonio swings at her, and in self-defence and frustration, Gloria strikes him on the head with a ham bone and kills him. Even though Gloria might be responsible for Antonio's death, the viewer is able to justify her actions as self-defence and her need for liberation. The spectator is somehow relieved when the rain washes away the blood on Dinero - her mother-in-law's lizard, the sole witness to the crime, and the only evidence pointing blame at Gloria. Due to the lack of premeditation in Antonio's death, and because he is seen as a potential threat to Gloria's safety, the killing does not seem deliberate. The homicide involves brute force, traditionally associated with masculinity; however, Gloria's embodiment of femininity and by extension, her victimhood, seems to take precedence. She is perceived as a victim before she is seen as perpetrator. ${ }^{9}$

In the martial arts studio Gloria "lets off steam" ("[se] desahoga") (I:3r:38) by swinging a wooden stick through the air in a way that mirrors her blow to Antonio's head with a ham bone (a gesture that has already magnificently been interpreted by Vinodh Venkatesh [362]). The homicide's case detective, who is also the man with whom Gloria is having an affair, walks in and criticizes her choice of activity, saying that, "hay modos para relajarse más normales" (I:3r:40). Although this remark can be interpreted differently, it might refer to the abnormality that such an action is performed by a woman. Aggression does not seem to be in accordance with a normal embodiment of femininity; Gloria reacts sternly, stating that normal ways do not work for her (I:3r:43). Gloria confesses to the police officer that she killed Antonio and demonstrates how. The 
repetition of her blows highlights her frustration and reveals an ambiguous line separating her dual position as victim and perpetrator. The officer hushes her, asserting, "no vaya de decir tonterías... puede ser peligroso" ( $\mathrm{r}: 32: 20)$, which once again undermines Gloria's agency by assuming that the world is dangerous for her not that she is a danger to it. She proclaims, "me da igual" (r:32:22), and falls to the floor before he leaves the room.

Gloria remains unhappy even after Antonio's death and the subsequent change in her societal role. Following her husband's death, his mother and eldest son move to the village. While this frees Gloria from all family responsibilities, she continues to feel downcast. The camera's movement in these last scenes highlights and situates Gloria's insignificance as it alternates its focus between her distressed face and various images that evoke feelings of loneliness. It spans the empty rooms of Gloria's house until she arrives at the balcony, where she observes an overwhelming number of windows across the street - an image that is also reflected in the glass door behind her when she steps onto the balcony. It is evident that Gloria feels overshadowed and insignificant in this overcrowded neighbourhood on the outskirts of Madrid. She leans over the balcony, implying that she might jump and kill herself. Using a subjective shot that has the viewer follow Gloria's perspective, the camera peers down to the cement road - where she would land - and watches a small piece of trash glide against the consuming grey concrete. In this moment, her youngest son, Miguel, enters the frame, and all thoughts of suicide immediately disappear. Suicide is therefore placed at the dramatic end of the movie and as a central turning point: the only moment in which Gloria is completely alone and just before her son comes back.

There is a parallel between homicide and suicide in this scene, in which Gloria's agency is questioned but also affirmed. Gloria's chosen suicide method points to Jaworski's ideas: not only do men "succeed" in taking their lives at much higher rates, the different methods used fall within a gendered division. For instance, "[t]raditionally men prefer to use methods considered more lethal, such as firearms [which are] male, masculine and active," whereas "female modes of engaging with suicide [are] less visually and physically violent and lethal," and viewed as more "reactive, manipulative and attention-seeking, configured by a fear of bodily disfigurement" ("The Gender-ing" 48). We see this in ¿Qué he hecho yo para merecer esto!! with Antonio's former lover, Ingrid Müller, who tries to die in peace by sitting on the couch with a glass of alcohol while eating pills as if they were candy (r:Or:Io). Her attempted suicide is portrayed as glamorous, to a certain extent, as well as inconsequential, 
which is demonstrated by how effortlessly Antonio "saves her life" (r:03:25). Jaworski questions the "passive and non-passive" dichotomy that dominates the discussion of suicidal intent because, she argues, within such a framework, the use of the gender binary plays an important role in interpreting the validity and seriousness of such intent ("The Gender-ing" 56-57 and The Gender I0, 43 and 67). Jaworski does not seek to challenge these numbers, but to consider why these gender differences exist, suggesting that suicide entails much nuance. Here Gloria's suicidal attempt could be read as masculine, as it is physically violent and lethal.

When the son enters the scene, the desire to commit suicide seems to have vanished. In this movie's final scene, Miguel and Gloria embrace, and Miguel explains how he hurried home as soon as he heard the news about his father. He proclaims, "esta casa necesita un hombre" (r:37:42). The ambiguity and multiple readings of this sentence have already been interpreted by several scholars (Jerez-Farrán I99; 214; Venkatesh 364). It implies that Gloria cannot exist outside the nuclear family, and that her son will fill the role of the man of the house. Like a knight in shining armour, Miguel rescues his mother, fills her void and maintains a patriarchal structure in which women - in this case, Gloria - cannot exist without men. However, Miguel does not represent a traditional type of masculinity: he is a young, gay and emasculated teenager, which adds humour to the already hyper-dramatic, uncomfortably comical scene. Miguel's queer sexuality and age challenge a patriarchal structure, because he does not fit the status quo for "man of the house," and the viewer's recognition that he veers from the conventional definition of masculinity reveals how his representation is largely influenced by gender expectations. Miguel's arrival marks not only the final scene of the film but also a transgression: Gloria will no longer seek to liberate herself from her housewife duties and instead seems to embrace the role of mother and housewife.

In Jaworki's study, the concepts of authorship and the body are deeply intertwined with suicide, and help explain the complexity of suicide as a gendered act. Jaworski utilizes Michael Foucault's notion of discourse and Judith Butler's theories about the gendered body to situate it within the discussion of suicide. ${ }^{\text {II }}$ The body is inherently material; however, inspired by Butler's ideas, Jaworski states: "it is impossible to theorize the body without meaningful reference to cultural meanings" ("The Gender-ing" 49). The way in which the body acquires gendered and sexed meanings originates in this "cultural compulsion" to assign and adopt significance (49), which is "constituted by processed practices governed by social and cultural norms" (49). As Butler suggests, this "sedimentation of gender norms ... has produced a set of corporeal styles which in reified form 
appear as the natural configuration of bodies into sexes existing in binary relation to one another" (I78). Jaworski uses this notion of performativity to explore the nuances of suicide, subvert the masculinized construction of suicide, and challenge normative ways of theorizing suicide and gender (see "The Gender-ing" 138). In the case of Almodóvar's film, on the one hand, Gloria's character remains unchanged because she returns to the role of housewife. On the other, her relationship to her body has dramatically shifted, since she decides not to take her own life.

As Jaworski illustrates in her study, authorship is also a central concept for interpreting suicide as a complex gendered notion. She begins by grappling with Foucault's discussion of the relationship between author and text. Following Foucault, Jaworski asserts, "the author does not precede the works," meaning that, in the case of suicide, the individual (as the author) would not precede the taking of his or her life. This suggests that the individual is not the agent or author of his or her death at all, but rather, the individual is suspended by something outside him or herself (See The Gender 39-40). Jaworski does not deny the individuality nor the deliberateness of the act of suicide. Instead, she argues that the responsibility for the act is nuanced, which suggests that there are additional social factors at play that not only highlight the lack of the agency's directionality, but also lend themselves to create a false sense of agency. This is significant in the filmic context as it can help us re-evaluate issues of auteurism vis-à-vis the agency of suicide, and question the extent to which the director is the one deciding who completes the act of suicide in the film. This act of suicide develops at the crossroads between social factors and the metaphorical agency of the director and actors in deciding who in the movie commits suicide. In this sense, the scene between Gloria and Miguel not only points towards the issue of agency but also of auteurism, as there seems to be a subtle identification between Almodóvar and Gloria's youngest son in their refusal of heterosexual normativity. The embrace between mother and son could be interpreted as a metaphorical embrace between director and actress, in which the former saves or gives life to the later. While needing the actors to make his film, the director wrote the script and, therefore, gave life to the actors but also took away these lives when necessary. The multiple levels of necessity between director and actors resemble the mother-son relationship in Almodóvar's movie, a relationship in which there is a death-life interdependence, highlighted by a potential suicide that has failed thanks to the appearance of the gay son.

Released in 1995, Maria Balletbò-Coll's Costa Brava is a movie that casts light on the position of women navigating old and new gender 
models in contemporary Spain. Anna, the protagonist, and her failed suicide also offer a compelling contrast to Gloria and her suicide attempt. Despite being two different women in two distinct historical contexts, Anna and Gloria illuminate the importance of sociological factors and gender when considering suicide. Unlike Gloria, Anna does not feel any kind of social imperative to assume a maternal role nor to care for others. Anna, a lesbian tour guide in her thirties who lives in downtown Barcelona, tries to pursue a career as a playwright and theater director. The differences between these two protagonists could not be more evident. In contrast to Gloria's relationship with her family, Anna's relationship with her lover Montserrat is one of partnership and mutual support. Unlike Gloria, Anna is independent; she exists for herself through the dedication to her work and her professional ambitions. In this way, Anna almost transcends the mystiques that trap Gloria and recognizes the problems that the housewife role poses. Yet there are some subtle but important parallels between the two, the most evident being that, while Gloria is a housewife, Anna mocks such expectations through her impersonation of a housewife in her monologue "Love Thy Neighbour," which invokes very strong similarities between these two women regarding traditional models of femininity that remain present in one's subconscious.

Anna spends much of her time filming herself in the role of a housewife, a role that provides her with a medium to highlight and confront existing gender presumptions and norms, which, paired with the film's comedy genre, allows the audience to consider such notions through humour. For instance, the film opens with a scene in which Anna's housewife character takes down her family's laundry in her patio in front of the imposing building of Antonio Gaudís Sagrada Familia. Anna's fictitious housewife blabbers on about her belief in women's rights, her socialist political affiliation, her somehow fulfilling relationship with her husband, and her struggle to accept her lesbian neighbour, which is especially ironic because, unlike the character, Anna is a lesbian. Despite considering herself to be a liberated, open-minded and modern woman, we can already see how her character externalizes and internalizes gender and sexual expectations and norms: she is the one doing the house chores and taking care of her children as she engages in homophobic discourse. Gender performance is extremely important in Costa Brava, where Anna's daily gender and sexual identity contrasts with that of the character she plays in her theatre/video project. What is interesting about Anna's performance is that the monologue helps her establish a distance between herself and the traditional housewife, while, at the same time, there is a 
clear identification between the two that increases over the course of the film, as the monologue's protagonist ends up falling in love with her lesbian neighbour.

The gradual identification between these two women (Anna and the protagonist of her monologue) is thought-provoking, as it echoes women's evolution in Spain in the mid-I990s in relation to the ghosts of the dictatorship. The model of the married heterosexual housewife is a bastion of the past that needs to be exorcized - in this case, through theatre - in order for Spanish women to be able to accept new models of femininity and sexual identities. Anna goes beyond the "feminine mystique" and the "feminist mystique" as she recognizes them, and performs and criticizes the problems of being both a working woman and a housewife. Yet, although Anna appears more "liberated" than Gloria, she is not completely free from gender prescriptions, not only because she is tasked with the majority of the housework, a challenge to the idea that same-sex couples divide more equally the household responsibilities, but also because she remains more of a victim of social pressures than she knows or is willing to admit. This is apparent in how she struggles to come to terms with Montserrat's bisexuality. Anna perceives two clear sexual categories assigned by society, heterosexual and homosexual, and she has difficulty understanding that Montserrat, her lover, and who identifies as bisexual, does not fit these classifications. While Anna's reaction is her own, it is based on a system of norms that she has internalized. Similarly, the way in which the audience analyzes Anna's witty personality connects with the rigidity of the gender dichotomy; the viewer judges her actions either as in accordance with or contrary to normative expectations. Bearing all this in mind, her comments and behaviour reveal latent gender presumptions, and her position in the film certainly inspires discussion that might ultimately aid Jaworski's goal to reframe discourse surrounding gender and suicide.

The scene in which Anna jokes and pretends that she will commit suicide opens up a discussion around internalized binaries and misogyny as well as the place of a professional career in relation to one's sexual and gender identity. In the scene, Montserrat calls Anna a man because she is professionally driven and "lives to work," claiming that the only difference between Anna and a man is that Anna “[doesn't] have a penis between her legs" (59:00). Anna's body becomes the verification of her womanhood even though she does not follow what is expected of women. This conversation is striking in that it addresses the central issue of how women are supposed to approach work (differently than men), and how femininity and masculinity are linked to one's professional persona. After 
Montserrat's recrimination, Anna explicitly negates her masculinity and shouts "I will kill myself right now!" (59:00), a sentence that she repeats while light-heartedly giving the impression that she will jump from the window.

The severity of the threat contrasts with the fact that the attempted suicide is evidently a joke. It seems that Anna dislikes the idea of being seen as a man because she feels empowered in her position as a working woman; or that she is trying to dispel the assumption that, because of her sexual orientation (being attracted to a woman), she has a masculine identity. She likely identifies with a more fluid version of gender, and with her response she scorns the fixed binary that defines gender roles. Or perhaps she does not mind being called a man at all, and instead is mocking women who react drastically to such a comment, by ridiculing the absurdity of killing oneself for violating gender norms. Any of these responses seem plausible and yet all of them reveal latent gender presumptions. Montserrat's comment implies that Anna deviates from gender prescriptions in some ways; however, Anna's reaction does not necessarily suggest that she perceives herself outside of the norm. It is important to notice that the initial remark that inspires the couple's discussion comes from Montserrat, Anna's bisexual partner, who through her sexuality challenges societal standards for women. Montserrat's sexuality is not limited to pleasing men or women, nor to childbearing and motherhood. Yet in their discussion, Anna criticizes Montserrat's divergences from the traditional binary and affirms that Anna's reason for being crazy and having these comedic suicidal thoughts is because of her relationship with someone who is attracted to both women and men.

It is worth noting how spatial elements and the body of the protagonists work in this scene: architecture and visibility are central not only in Anna's enactment of suicide, but also to the protagonists' sexual identities throughout the film. As they argue, each woman appears in one window - a liminal space between the exterior of the street and the interior of the home - and they are filmed from the exterior. Kim Yeon Soo and Jaume Martí-Olivella have pointed out the importance of the unseen in Costa Brava and noted the fact that there are no kisses nor other evidence of sexual intimacy between the protagonists (Yeon Soo 474-475) as well as the lack of "scopic gratification" in the film (Martí-Olivella 8I). The suicide scene further complicates the importance of visibility, as it shows the uncomfortable position of the couple in relation to the public eye (the exterior) and how their relationship is hidden inside the domain of the house. $^{12}$ Anna makes her "suicide joke" as she converses with Montserrat from the window; even if it is expressed in the same playful tone that 
characterizes this movie, the suicide quip unveils the difficulty and danger for the two protagonists to be accepted and to be able to show their love outside the home.

In this scene, and throughout the film, architecture is represented as imposing, limiting and incarcerating; the cinematic framing of the buildings becomes fundamental to metaphorically signal issues of visibility for the lesbian couple. The importance of architecture throughout the movie, and especially in this scene of failed suicide, underscores Anna and Montserrat's vulnerable and liminal position. Their first conversation about their sexual identity occurs in front of the Pavilion of the Single Mothers (the Pavelló Rosa in the Recinte de la Maternitat), a building that clandestinely sheltered single mothers during child birth and their newborns from 1927 to 1974 . As the camera shifts roughly and repeatedly from the building's wall to the two women speaking in a series of close-up shots, Montserrat confesses that she was once in love with a woman, and Anna explains that "People don't label me as a lesbian, they label me as nuts" (19:00). The camera goes back and forth from the architecture to their conversation, creating a parallel between acknowledging and talking about one's own sexual identity and being outside architectural structures. At the same time the scene transmits a sense of confinement and reclusion, since we have no knowledge of how isolated these two women are in relation to passers-by. Similarly, when Montserrat goes on her date with Jordi in the hypermodern environment of the Vila Olímpica, the architectural straight and white lines express how the buildings' modernity does not necessarily correspond to modern forms of living. On the contrary: this is the moment in which Montserrat has to act more feminine, and the only time in the film that she wears a skirt, pantyhose and high heels.. ${ }^{13}$ Modern architecture correlates with Montserrat's acceptance of what has been expected of her in a public space and resonates with her own words when she explains to Anna that in her field (engineering), whenever there is a party, men are accompanied by women, and not women by women because, "It is not socially acceptable" (39:00). Interestingly enough, during Montserrat's date with Jordi, Anna stays at home and does Tai chi on her balcony - emphasizing again issues of visibility and invisibility but also, as Gloria did in ¿Qué he hecho yo para merecer esto!!, looking for a physical activity that is outside the conventions of traditional prescriptions of Spanish womanhood. ${ }^{\text {I4 }}$

How their sexuality, their housework and professional aspirations are negotiated are clearly some of the points of contention between Anna and Montserrat; even when they are presented in a trivial, casual and humorous way, they still seem more difficult to overcome because of their 
isolation. The professional challenges they encounter in Barcelona make them flee to San Francisco. Although this is not perceived as a forced exile, but more of a choice that involves hope, optimism and a sense of play, the new start in San Francisco originates in the fact that Catalan society does not recognize Anna's work - "the producers say that a monologue from a housewife's point of view is of no interest whatsoever" (r:03:00) - and, in the case of Montserrat, she also explains how she is treated differently at work because she is a woman (33:00). Feeling simultaneously rejected with all the pain that these rejections carry -, the possibility of leaving strengthens their relationship. Catalan society is not open nor equal enough, and this obliges them to flee to San Francisco, imagined as a utopic community that would allow them to pursue their careers while they continue to live together. Montserrat's Jewishness functions here as another mark of marginalization: lesbians are marginalized and persecuted within the Catalan and Spanish communities like the Jews were during the Spanish Reconquista. The agency to migrate, although presented and perceived as a free choice, is influenced by transnational, cultural and economic forces as well as sexual and gender subjectivities. In fact, it is unclear if this new beginning in San Francisco will truly lead to a liberated life, or if it will cause them to quarrel and separate, as it happened with the couple that Anna and Montserrat observe while walking at night near the Fonts de Montjuïc.

The natural space of the area of the Costa Brava has been read as providing "an all-embracing category for them to locate themselves [Anna and Montserrat] anywhere" (Yeon Soo 474). However, the Costa Brava location could also have been chosen to fulfill the narrative requirement of finding a place that would allow Anna's work and love to remain undivided: "Costa Brava Tours" is the name of the company for which Anna works, and she visits Costa Brava with the tourists. It is also the abrupt yet embracing landscape where Anna and Montserrat meet, where they kiss and make love for the first time - although off-camera - and where the couple spends a short vacation before Montserrat leaves for San Francisco, anticipating that they will find a place together where they can both advance their professional life and love. In fact, their relationship gets stronger as they support each other's careers: Montserrat helps Anna meet with the diva, her ex-lover, Marta L. Puig. Similarly, Anna calls her former colleague in New York to compile a list of the businesses that might be able to employ Montserrat, which leads to Montserrat's new job in the private research business in San Francisco after she has expressed her frustration with teaching, sexism and bureaucracy at the University of Barcelona. Ultimately, the movie underscores the necessity of finding a job where 
one's own gender and sexual identities are welcomed and integrated, reflected clearly in Anna's pursuit of a writing career: she writes her first film script about female hypocrisy in Catalonia, evidently expressing her concerns about social gender prescriptions. Finally, the film's title, Costa Brava, can be read in relation to Anna's theatrical play, Love Thy Neighbour, and the title of Marta L. Puig's play Oedipus Queen in a game of inter-referentiality. The autobiographical content of Anna's play (the protagonist is Anna's doppelgänger of Anna) serves as a playful questioning of the autobiographical references in Marta L. Puig's Oedipus Queen and Marta Balletbò-Coll's Costa Brava.

The issue of agency and auteurism in relation to suicide cannot be underestimated in this film. As with Almodóvar's ¿Qué he hecho yo para merecer esto!!, the scene in which a failed suicide is evoked points directly to the issue of auteurism and to the reconstruction of the Oedipal link between the actress and the film director. Because Marta Balletbò-Coll is both the director and the protagonist of the film, Costa Brava not only challenges the idea that the director has more to say than the actress and has agency over her actions, but also offers an elaborate dynamic around the self-referentiality of the filmic text. We have already signalled the close identification between Anna and her monologue's protagonist, a relation that Kim Yeon Soo further comments in this way: "As the parallel image of the director herself, Anna in the film writes her script" (482). Elizabeth Shelley Gunn has also underscored the importance of self-referentiality in Costa Brava. She analyzes the extent to which the problems that Anna encounters in order to have her theatrical script recognized are similar to the challenges that Marta Balletbò-Coll faced as a film director (Gunn I34). Furthermore, Balletbò-Coll studied in New York, and the United States is also the point of reference for Anna and her desire to move to San Francisco. Martí-Olivella has commented on how "Balletbò-Coll has been extremely resourceful in incorporating her personal success in the United States both diegetically and extradiegetically" (93), as the film won the San Francisco International Lesbian \& Gay Film Festival in 1995 (see IMDb). In this sense the movie resembles a Russian doll, in which alter ego figures signal and inhabit one another.

Marta L. Puig is a secondary character in Costa Brava who incarnates a famous Catalan actress and who is also Anna's ex- lover. Her play Oedipus Queen serves to rewrite an unconventional Oedipal myth, a familial narrative (we cannot forget that the title of the movie, in English, is Family Album) in which the lack of blood ties and the absence of male figures signals the need for women to help each other (Montserrat helps Anna get assistance from Marta), but also to help oneself achieve success (it is 
ultimately Marta L. Puig that helps Marta Balletbò-Coll's alter ego). Gunn has considered the movie "a burlesque imitation of the Oedipus complex" (I34), and it is true that Marta Balletbò-Coll points at a new Oedipal triad in which a female director gives birth to herself (the actress), and the phallus seems to be a Catalan culture that needs to be rewritten and reconsidered. This phallus is not a phallus borne by a man, but it serves the film director and actress to form their ideas. ${ }^{15}$ The suicide scene is essential, as it acknowledges that the lack of the masculine organ (penis) is not an impediment for the artist to create and thus subvert the idea of the feminist mystique and to expose that, through one's own artistic work and as Anna Giralt-Romaguera and Marta Balletbò-Coll do - women can in fact be equal to men.

This article has argued that failed suicide is key in these two films in order to understand the two female protagonists' position vis-à-vis the surrounding and changing gender norms and expectations. Suicide is central in both movies to represent the protagonists' relationship with both their paid and unpaid labor, as well as their work inside and outside of the house, in addition to being fundamental for elucidating their relation with their own body and sense of agency. As a way of conclusion we can say that failed suicide in these two films serves as a symbol of resistance to expected ideas of femininity and issues related to "gender trouble:" if the feminine is underlined by the fact that the two movies portray a failed suicide, this failure causes Gloria to accept a new subject position as mother and housewife; and in the case of Anna, it highlights the dangerous position of the lesbian couple. Moreover, suicide is important to understand how agency works in the cinematic sphere and to metaphorically illustrate the relationship between director and actress in regards to their agency and interdependence. In both cases, the power relationship between director and actress is resolved through a rewriting of the Oedipus complex in which suicide is directly linked to issues of life and death as well as to the mother-son and mother-daughter relationship.

Whitman College - University of British Columbia

NOTES

I Seminal studies about gender in ¿Qué he hecho yo para merecer esto!! include the works by Vinodh Venkatesh and Carlos Jerez-Farrán. See Elizabeth Shelley Gunn, for a gender studies approach to Costa Brava (Family Album). 
2 Comedy is not the primary genre of these movies, yet the comedic effect regarding suicide is key and evident in both. If ¿Qué he hecho yo para merecer esto!! is a melodramatic movie, Costa Brava falls within a Romance genre, yet, comedy is certainly prevalent and its comic relief assists in evoking similar themes regarding the gendered body and authorship in suicide.

3 La movida madrileña has been defined by Rosi Song and William J. Nichols as coming "to epitomize change and the perceived arrival of modernity in postFranco Spain" (I). For further readings on cultural, sociological and political phenomena, see Maite Usoz de la Fuente's Urban Space, Identity and Postmodernity in I98os Spain: Rethinking the Movida, and José Luis MorenoRuiz's La movida modernosa: crónica de una imbecilidad política.

4 There are several ways to read these differences. One possible reading is that Costa Brava might have experienced a double marginalization, one for being located in a periphery within Spain, and another one for being about the love relationship between two women.

5 See Victoria L. Enders and Pamela B. Radcliff,'s Constructing Spanish Womanhood, as well as Aurora's Morcillo's The Seduction of Modern Spain.

6 It is also telling that while there is no difference between women in Spain and Catalonia, in the case of men, it seems that Catalan men have lower rates of suicide in Catalonia than in Spain. It is also important to note that these statistics predate the 2008 economic crisis in Spain. After 2008, the number of suicide attempts rose.

7 We cannot forget that, as women have become part of Spain's paid workforce, their work outside the home has not necessarily correlated with a shift in domestic responsibilities.

8 Betty Friedan stresses from the beginning of her book the silent unhappiness of suburban American wives, whose life was supposed to be fulfilled by caring for children, their husbands and the achievement of femininity (15-16).

9 It is worth mentioning that, for centuries, homicide has been socially constructed and perceived as a form of masculine power. Following studies by Mary Hartman and Kerry Segrave, Rosa Sarabia explores how women kill differently and less frequently than men: "Si bien pareciera haber una relación proporcional directa entre mayor 'liberación,' mayor crimen, o sea que con la demolición del papel tradicional de la mujer se ha llevado a cabo 'una masculinización de la conducta femenina,' también lo es el hecho de que las grandes criminales (grandeza numérica) pertenecen al pasado." Moreover, and following Sarabia's work, most female killers use poison as method, are circumscribed to the domestic space for their practices, and their victims are close family members without power, such as children, elderly and sick people. One could question to what extent Gloria represents a stereotypical 
woman considering that she kills her husband, and the violence of her act, resembling a masculine gesture that she has observed.

IO Following Foucault, Jaworski defines discourse as the "practices that systematically form the objects [in this case suicide] of which they speak" (The Gender 9).

II According to the authors of the newspaper project Isla Ignorada, although Spain is one of the most advanced countries in terms of LGTB rights, lesbians do not have the same rights as the rest of the population in the case of maternity and filiation; yet "muchas ejercen sus derechos en la sombra. La invisibilidad se presenta en ocasiones como libre elección, cuando en realidad es el marcador de una salud social deficiente" ("Isla Ignorada").

I2 Several critics have highlighted that our bodies relate to space and architecture through our gendered subjectivity. At the same time, public spaces have often been designed without taking into account this gendered subjectivity and physical differences of the gendered body. Elizabeth Grosz' Volatile Bodies: Toward a Corporeal Feminism and Colin Davies's Thinking About Architecture: An Introduction to Architectural Theory are illuminating readings in this regard.

I3 One could consider that Costa Brava is alluding here to ¿Qué he hecho yo para merecer esto!! . Another important intertext that we could consider in Costa Brava is Esther Tusquets's El mismo mar de todos los veranos (1978).

I4 Not in vain Anna writes a monologue and not a play, and equates her monologue to masturbation. She also shouts "Marta, Marta, Merda" (I8:00), three names that might be read as a play on the Oedipal structure and the potential of triangular love. We can also speculate about the unknown name of the neighbour in Anna's play, a missing name that could then be substituted in different ways such as "Love Thy Neighbour"- "Love the Lesbian"- "Love Yourself."

\section{WORKS CITED}

A Llins on, MAR к. A Spanish Labyrinth: The Films of Pedro Almodóvar. New York, London: I.B. Tauris, 2OOI.

ARÁN BARÉS, MARÍA, ROSA GISPERT ET AL. "Evolución temporal y distribución geográfica de la mortalidad por suicidio en Cataluña y España (1986-2002)." Gaceta Sanitaria 20. 6 (2006): 473-480.

B utle R, Judith. Gender Trouble: Tenth Anniversary Edition. New York: Routledge, I999.

"Costa Brava Awards." The Internet Movie Database. N.d. N. pag. Web. Costa Brava (Family Album). Dir. Marta Balletbò-Coll. Costa Brava Films, I995. 
DA vies, Co Lin. Thinking About Architecture: An Introduction to Architectural

Theory. London: Laurence King Publishing, 201 I.

ENDERS, Victoria lorée, AND PAMEla beth RAdCliff, eds. Constructing

Spanish Womanhood. New York: State University of New York Press, I999.

frechette, Julie. “Gender and Feminity: Motherhood." Ed. Mary E. Kosut.

Encyclopedia of Gender in Media. Worcester: Worcester State UP, 20I2. I27-I29.

F RIEDAN, BETty. The Feminine Mystique. New York: Dell, I963.

GR OSZ, ElizABeth. Volatile Bodies: Toward a Corporeal Feminism. Bloomington:

Indiana UP, I994.

GUnN, Elizabeth SHElley. "The Impossible Subject: Reiterating Lesbianisms in

Late Twentieth Century Spain." Diss. U of North Carolina at Chapel Hill, 2004.

"Isla Ignorada." Verkami. N.d. N.pag. I3 July 2017. Web.

JA W OR S KI, KA T RIN A. "The Gender-ing of Suicide." Australian Feminist Studies 25.63

(2OIO): 47-6I.

- The Gender of Suicide. Knowledge Production, Theory and Suicidology. New

York: Routledge, 2OI4.

JEREZ-FARRÁN, CARLOS. "De la tradición a la transgresión: el ambivalente final de

Qué he hecho yo para merecer esto? de Pedro Almodóvar." Bulletin of Hispanic

Studies 88.2 (2OII): 197-2I8.

maRTí-o LiVELla, JA ume. "Textual Screens and City Landscapes: Barcelona and the Touristic Gaze." Chasqui 34. 2 (2005): 78-94.

m or cillo, A u r ora. The Seduction of Modern Spain: The Female Body and the

Francoist Body Politic. Lewisburg: Bucknell UP, 2010.

MORENO-RUIZ, JOSÉ LUIS. La movida modernosa: crónica de una imbecilidad política. Madrid: La Felguera Editores, 2016.

NiCH OLS, WiLliam J. "Back to the Future: Towards a Cultural Archive of La

Movida." Toward a Cultural Archive of la Movida: Back to the Future. Eds.

William J. Nichols and H. Rosi Song. Madison: Fairleigh Dickinson, 20I4. I-I5. ¿Qué he hecho yo para merecer esto!! Dir. Pedro Almodóvar. Tesauro, 1984. SARABia, ros A. "Texto e imagen en 'De suicidios' de Max Aub." Diálogos de saberes. XXXV International Congress of the Latin American Studies Association, April 29 - May I, 20I7, Pontificia Universidad Católica de Lima, Perú.

StRauss, FREDERIC. Almodóvar on Almodóvar. Trans. Yves Baignéres. London: Faber and Faber, 1996.

TUSQUETS, ESTHER. El mismo mar de todos los veranos. Barcelona, Lumen, 1978. uSOZ DE LA F U EN TE, MAITE. Urban Space, Identity and Postmodernity in I980s Spain: Rethinking the Movida. Cambridge: Modern Humanities Research Association/Routledge, 2015.

VENKA TESh, Vin ODH. “Queerying and Locating Pedro Almodóvar's ¿Qué he hecho yo para merecer esto!!" Modern Language Notes I29.2 (2014): 352-366. 
WhEELER, DunCAN. "The (Post)Feminist Condition: Women Filmmakers in Spain." Feminist Media Studies I6. 6 (2016): 1057-1077.

YE ON-So 0, K IM. "Family Album as a Portable Home: Marta Balletbò-Coll's Costa Brava" Revista Canadiense de Estudios Hispánicos 27.3 (2003): 469-84. 